\title{
A CELERIDADE PROCESSUAL: UMA PESQUISA EMPÍRICA NOS CARTÓRIOS JUDICIAIS DA CAPITAL DO RIO DE JANEIRO (2017)
}

The procedural speed: an empirical research in the notary offices of the capital of Rio de Janeiro (2017)

La velocidad procesal: una investigación empírica en las notarías de la capital carioca (2017)

Received: august $/ 2020$

Accepted: september/2020

Available online: september/2020

Ricardo Alves de Lima, Doutorando em Direito, FADISP - Faculdade Autônoma de

Direito de São Paulo, Brasil. E-mail: ricardo@pedroalvesdelima.com.br

Maria Cristina Pedro Alves de Lima, Doutoranda em Direito, DINTER UNIFACVEST

/ Universidade Veiga de Almeida, Brasil. E-mail: cristina@excelsu.com.br

\section{RESENHA}

A presente resenha tem origem em uma pesquisa empírica nos cartórios judiciais da capital do Rio de Janeiro, desenvolvida pelo autor Wagner Brito, sendo a base de sua tese de doutorado intitulada, posteriormente publicada como livro.

RBPPD/BRJPD | Vol. 2 | n. 3 | p. 334-338, 2020. 
A pesquisa mesmo focada no Poder Judiciário carioca, representa desde aquela época a realidade da justiça morosa no Brasil, do acúmulo de processo, da escassez de recursos públicos para administrar a máquina judiciária e dos inúmeros recursos processuais.

Os resenhistas que residem São Paulo, capital, podem afirmar que neste Estado a realidade nos últimos anos se assemelha com a relatada pelo autor, pois, já presenciou, por diversas vezes, a morosidade processual por inúmeros motivos, em especial pelos prazos paralelos apresentados pelos cartórios judiciais, especialmente em processos ainda físicos, conquanto, estarmos em outra realidade pela constante implantação dos processos judiciais eletrônicos, os quais, trazem sobrevida aos interesses urgentes dos cidadãos.

O autor relata que através de uma observação diferenciada das atividades cartorárias definiu o objeto da sua pesquisa, tomando como foco o encontro de respostas, sendo a principal delas, como de fato funcionava o cartório judicial, especialmente quanto ao cumprimento de prazos.

Para o autor ficou claro nas suas observações que os cartórios parecem uma terra sem lei, ou melhor, um campo próprio, com uma lei própria, exercida em um ritmo e dimensão completamente diferentes da literatura jurídica. Deixa-se claro que essa "terra de ninguém", traz muitas consequências para quem depende da máquina judiciária para buscar e se fazer justiça.

Em sua pesquisa o autor passou a ter como questão principal a investigação dos fatores determinantes da marcha processual. $\mathrm{O}$ autor utilizou de pesquisa empírica para responder às questões burocráticas que envolvem todo o contexto procedimental, trazendo respostas concretas quanto à celeridade processual.

RBPPD/BRJPD | Vol. 2 | n. 3 | p. 334-338, 2020. 
A questão explorada foi de verificar em que medida as práticas cartoriais, as relações e as representações de seus servidores, podem contribuir para o fluxo do processo, no resultado da ação judicial, e para o pleno exercício dos direitos civis.

Percebeu-se que as práticas dos serventuários, quando direcionadas a modular o normal fluxo processual, afetam diretamente a sensibilidade dos cidadãos, podendo trazer conjuntamente um sentimento de insegurança jurídica, e sobretudo, de descrédito do Poder Judiciário brasileiro, passando a se admitir uma ampla noção de injustiça e de impunidade.

A resposta interpretativa extraída da pesquisa do autor busca evidenciar de qual maneira o sentimento de justiça depende de como os conflitos de interesses têm sido administrados. Conforme direciona, seria esperado que estes conflitos que deixam de ser resolvidos de comum acordo pelas partes, seriam resolvidos pelo Poder Judiciário de forma rápida e justa.

Contudo, o autor traz que a decisão ainda que realizada rigorosamente, tiver sido proferia em período muito além do que a própria lei estabelece, corre sério risco de não ser reconhecida como justa, seja pelo senso comum, ou até mesmo pelos operadores do Direito. O autor expressa que esta morosidade fere o que estabelece a Constituição Federal de 1988, que formaliza instrumentos para garantir o acesso de todos à justiça e à duração razoável de um processo.

Como ficou observado nesta pesquisa, há dois tipos de prazos, o prazo próprio ou o impróprio. Ficou claramente demonstrado que os cartórios pesquisados no Rio de Janeiro tinham seus próprios prazos, ou seja, uma gama de prazos impróprios, e destoantes da legalidade processual.

RBPPD/BRJPD | Vol. 2 | n. 3 | p. 334-338, 2020. 
Os resenhistas em sua atuação como advogados em São Paulo, passaram por diversas situações na mesma época em que a pesquisa foi realizada, sofrendo por diversas vezes perdas consideráveis, jurídicas ou financeiras, causadas pela morosidade processual advinda de prazos impróprios aplicados paralelamente pelos cartórios, que influenciava de modo concreto na temporalidade do processo. Com esta observação comparativa entre os dois estados, conclui-se que o resultado da referida pesquisa é uma realidade enfrentado não só pelo estado do Rio de Janeiro, mas por todo Brasil.

Com esta pesquisa empírica é possível observar de uma forma mais detalhada, e ter uma resposta concreta sobre questões procedimentais (internos e externos) que merecem reflexão, podendo assim, resolver fatores pontuais que muitas vezes ocasionam interferência em um número mais amplo de procedimentos, e lhe causam atrasos em seu natural processamento. Detalhes que passam por indiferentes, mas trazem resultados negativos a um contexto maior.

Como exercer o monopólio processual da solução de conflitos dentro de um Estado Democrático de Direito, se aqueles que devem imperar pelo absoluto cumprimento da lei, e respeitar aqueles princípios processuais que quando foram esculpidos vieram impregnados de um sentido de equilíbrio para todas as partes que são envolvidas dentro de um sistema judicial, o qual, serve, sobretudo, para amenizar o sofrimento, seja psicológico, financeiro e social, causado pela morosidade processual, que mata mais sonhos do que o próprio conflito inicial. Jogam-se os direitos fundamentais do cidadão na área mais obscura do esquecimento.

Nesta linha, resta evidenciado pela pesquisa empírica todas as problemáticas que envolvem essas nefastas práticas judiciárias, seja quando presentes escolhas insensatas, quiçá na figura de uma burocracia desmedida, cheia de intenções, ou mesmo desprovida 
daquelas, mas que trazem um desequilíbrio entre os que dependem de uma solução rápida de seus problemas.

Que o resultado da pesquisa, que representa todo um conhecimento jurídico acerca de tais intervenções, possa subsidiar a formulação de políticas que visem ao aperfeiçoamento da efetividade de nosso sistema judicial.

\section{REFERÊNCIA}

Brito, Wagner. A celeridade processual: uma pesquisa empírica nos cartórios judiciais da capital do Rio de Janeiro. 1. ed. Rio de Janeiro: Autografia, 2017. 150 p.

RBPPD/BRJPD | Vol. 2 | n. 3 | p. 334-338, 2020. 